\title{
Biomarkers for The Recognition of SARS-CoV2-Virus and in the Prediction of COVID-19 Infection Severity
}

\author{
Yasmin Anum Mohd Yusof ${ }^{1}$, Mainul Haque ${ }^{2 *}$
}

$\mathrm{T}$ The outbreak of Severe Acute Respiratory Syndrome Coronavirus 2 (SARS-CoV-2) infection since December 2019 has provided clinicians with a battery of laboratory tests and imaging tools to back up in the speedy pin-pointing of high-risk COVID-19 victims, enabling them to make the most optimized treatments for COVID-19 patients lowering the mortality rates. The biochemical tests include inflammatory markers, hematological parameters, liver and kidney functions.

COVID-19 disease was initially discovered in Wuhan, China, in a conglomeration among inhabitants of the state who presented with unusual symptoms of pneumonia in December 2019. Nevertheless, in late January 2020, it was dyed-in-the-wool as a case of infection caused by the SARV-CoV-2 virus. The World Health Organization (WHO) designated the illness as COVID19 and declared it a pandemic on 11 March 2020 (WHO, 2020). Since then, the disease has spread globally, altering people's lifestyles as they grapple and cope with the disease. "Globally, as of 4:14pm CET, 29 December 2021, there have been 281,808,270 confirmed cases of COVID-19, including $5,411,759$ deaths, reported to WHO. As of 27 December 2021, a total of $8,687,201,202$ vaccine doses have been administered" (WHO, 2021).

\footnotetext{
${ }^{1}$ Unit of Biochemistry, Faculty of Medicine and Defence Health, Universiti Pertahanan Nasional Malaysia (National Defence University of Malaysia), Kem Perdana Sungai Besi, 57000 Kuala Lumpur, Malaysia. Email: yasmin.anum@upnm.edu.my.

${ }^{2}$ Unit of Pharmacology, Faculty of Medicine and Defence Health, Universiti Pertahanan Nasional Malaysia (National Defence University of Malaysia), 57000 Kuala Lumpur, Malaysia.

Email: runurono@gmail.com.
}

The massive outbreak of COVID-19 has blazed a trail to the introduction of a battery of biochemical and hematological parameters to monitor the progression of the disease (Udugama et al., 2020). The treatment outcome and prognostic indicators among patients infected with the COVID-19 virus became important issues (Wiersinga et al., 2020). They include inflammatory markers $\mathrm{C}$ reactive protein (CRP), Interleukin-6 (IL-6), Interleukin-10 (IL-10) and tumor necrosis factor-alpha (TNF- $\alpha$ ), hemostatic system profile such as D-dimer, platelets, activated Partial Thromboplastin Time (aPTT), and serum biochemical tests for liver and kidney functions (Letelier et al., 2021). In severely infected patients, the SARV-CoV-2 virus induces lung inflammation that leads to a cytokine storm accompanied by an elevation of inflammatory biological indicators such as C-reactive protein (CRP), IL-6, IL-10, and TNF- $\alpha$ (Costela-Ruiz et al., 2020; Melo et al., 2021). Excessive inflammation is highly associated with causing more severe ailment and even death among COVID-19 infected cases (Roberts et al., 2021).

CRP is labeled as an acute-phase protein that is raised during the early inflammation phase of the disease (Jain et al., 2011) and interestingly bring into being to be preeminent among the majority of patients with COVID-19 infection (Yang et al., 2020; Ali et al., 2021). Nonetheless, CRP elevation is seldom seen in viral diseases (Jeon et al., 2017). In the current COVID19 pandemic, inflammation caused by the virus's infection may be the primary reason for CRP elevation, which further activates the complement system of the macrophages and promotes uncontrolled inflammatory responses (Noris et al., 2020; Luan et al., 2021). This wild initiation of complement persuaded by the SARS-CoV-2 in the pulmonary tree and additional vital organs act as a foremost protagonist in acute and chronic 
inflammation, endothelial cell dysfunction, thrombus formation, and intravascular coagulation, and eventually leads to several organ calamities and bereavement (Noris et al., 2020; Luan et al., 2021). In the early stage of inflammation, cytokines, for instance, IL- $6, \mathrm{TNF}-\alpha$ stimulate the hepatocyte to produce CRP. The cytokine storm elicited among grave COVID-19 victims correlates highly with CRP elevation (Luan et al., 2021; Stringer et al., 2021).

Research conducted by Stringer et al. observed that a cut-off of CRP values $>40 \mathrm{mg} / \mathrm{L}$ was associated with mortality among the UK cohorts from several hospitals, which gave clinicians guidelines for proper treatment decisions and advanced care planning (Stringer et al., 2021). Those COVID-19 infected patients who passed away, the median CRP level was $86 \mathrm{mg} / \mathrm{L}$ (48 mg/L- $173.5 \mathrm{mg} / \mathrm{L})$, equated to $53 \mathrm{mg} / \mathrm{L}$ (16 mg/L-109 $\mathrm{mg} / \mathrm{L}$ ) among patients who recovered from the SARS-CoV-2. One more research conducted among one hundred forty COVID-19 cases with moderate to severe bronchopneumonia requiring oxygen supplementation admitted in a hospital in Wuhan, China, found that patients with low oxygen saturation ( $\mathrm{SpO} 2 \leq 90 \%$ ) had significantly higher levels of CRP (median $76.5 \mathrm{mg} / \mathrm{L})$ than patients with high oxygen saturation (SpO2>90\%) (median $12.7 \mathrm{mg} / \mathrm{L})$, demonstrating that appalling cases with extreme lung involvement have raised levels of CRP (Xie et al., 2020a). Wang also found a similar correlation whereby CRP levels in the initial phase of COVID-19 were definitely interrelated with severe pulmonary pathology (Wang et al., 2020).

D-dimer is a fibrin breakdown compound produced by plasmininduced fibrinolysis and is used as a biomarker for thrombotic disorder (Favresse et al., 2018; Riley et al., 2016). A marked elevation of D-dimer ( $\geq 1.5-2.0 \mathrm{ug} / \mathrm{ml})$ is an precise decipher of hospital mortality in patients with COVID-19 (Poudel et al., 2021; Yao et al., 2020). D-dimer elevation was detected in $75 \%$ of patients admitted to a hospital in Wuhan, China (184/248). The increase was significantly interrelated to the lethality of the illness as determined by clinical staging and chest CT staging (Yao et al., 2020). Many researches have made known that COVID-19 inclines patients to thrombosis in both arteries and veins, suggesting that measuring $\mathrm{D}$-dimer can be a good prognosticator of thrombosis (Poudel et al., 2020; Yao et al., 2020; Cui et al., 2020).

COVID-19-associated coagulopathy can be classified into 3 stages: stage 1 shows a raised D-dimer, stage 2 shows an eminent D-dimer along with somewhat protracted PT/INR and aPTT, and trivial thrombocytopenia and stage 3 shows lifethreatening COVID-19 infection and laboratory-based research findings shows the disease progressing towards classic disseminated intravascular coagulation (DIC) (Thachil et al., 2020). D-dimer is a routine measurement upon admission in some hospitals to foresee the mortality of patients with COVID19. Its increased levels are also closely linked with inflammatory indicators such as CRP, IL-6, and TNF- $\alpha$ (Yu et al., 2020). A meta-analysis study by Zhan et al. showed that the prognostic relevance of $\mathrm{D}$-dimer in predicting the severity, mortality, and venous thromboembolism in COVID-19 patients was shown to be $77 \%, 75 \%$, and $90 \%$, respectively (Zhan et al., 2021).

Hematological changes are common among COVID-19 patients, including reduced lymphocyte and platelet counts and prolonged aPTT (Xu et al., 2020). Additionally, it has been revealed that lymphopenia can represent a critical laboratory finding and possess a predictive analytical value. Neutrophil/lymphocyte (NLR) ratio and peak platelet/lymphocyte ratio (PLR) also bear the possibility to represent analytical value in determining severe cases (Terpos et al., 2020). Similarly, multiple studies reported that lower lymphocytes $(\mathrm{p}<0.001)$, platelets $(\mathrm{p}<0.001)$, and higher white blood cells $(p<0.001)$, neutrophils $(p<0.001)$, NLR $(p<0.001)$, PLR ( $\mathrm{p}<0.001)$, and Lymphocyte-Monocyte ratio $(\mathrm{p}=0.011)$ found in COVID-19 cases were statistically significantly different than healthy controls (Khalid et al., 2021; Waris et al., 2021). The reduced number of lymphocytes is in parallel with the SARS-CoV-2 illness severity and intensification of mortality (Waris et al., 2021; Tavakolpour et al., 2020). It was further explained that the $\mathrm{T}$ lymphocytes are essential for eradicating infectious viral particles (Tavakolpour et al., 2020; Härter et al., 2020).

Research conducted among 1099 patients from 31 territories in China exhibited that $82.1 \%$ of patients had lymphopenia, $36.2 \%$ had thrombocytopenia, and $33.7 \%$ had leukopenia (Guan et al., 2020). A meta-analysis of 7,613 SARS-CoV-19 cases, as published from April 2020, reported thrombocytopaenia among patients with severe disease compared to those with non-severe disease, with the deceased having a considerably lower platelet count than the recovered cases (Jiang et al., 2020). Platelets work together as the crow flies with viruses via several receptors, together with Toll-like receptors, triggering inflammatory and immunological responses, engulfing and aggregating the viruses, thereby suppressing their infections (Seyoum et al., 2018; Li et al., 2020a; Wool and Miller, 2021). Thrombocytopenia in SARS-CoV-2 patients (Li et al., 2020b) could be instigated by platelet activation that is followed by elimination by the reticuloendothelial system; amplified endothelial damage promotes platelet elimination process; development of platelet autoantibody that consequently leads to 
platelet removal by spleen/liver; and poor function of marrow/megakaryocyte (Wool and Miller, 2021).

As a result of COVID-19 complications, organ failure poses further challenges among clinicians in treating patients infected with the COVID-19 (Shang et al., 2020; Wiersinga et al., 2020). Liver failure can be detected by simple, inexpensive biochemical tests such as Urea nitrogen, liver enzymes, and kidney metabolites (Lala et al., 2021; Sharma and Nagalli, 2021). A meta-analysis of 24 pieces of research with confirmed COVID-19 patients by Sharma et al. proposes that acute liver injury and raised up liver enzymes such as ALT and AST were significantly associated with severity of SARS-CoV-2 (Sharma et al., 2021). A meta-analysis of 29 pieces of research with confirmed corona viral infected cases by Singh et al. suggests that comorbid chronic kidney disease (CKD) (overall prevalence of 9.7\%) and acute kidney injury (AKI) (overall prevalence $11.6 \%$ ) were significantly associated with COVID19 disease severity (Singh et al., 2021).

Nonetheless, there are quite a lot of diagnostics systems accessible for uncovering coronavirus disease 2019 infection. These approaches are not cheap enough, particularly for lowmiddle income countries (LMICs), and they also have hands-on problems and issues (Mariappan et al., 2021). Thereby, a compact, low-priced, and cost-effective method that will precisely spot the COVID-19 viral infection and assess disease progression is an urgent need, especially for the marginalized communities around the globe (Mariappan et al., 2021; Gupta et al., 2020). Finally, this paper suggests combining COVID-19 clinical and laboratory data and associating the disease's natural course of progression might be of great help to clinicians (Xie et al., 2020b). Multiple diagnostic parameters should be monitored rather than a single value (Samprathi and Jayashree, 2021). National and international COVID-19 management guidelines should be tailored to the specific needs of each patient, and healthcare settings are critically essential (Samprathi and Jayashree, 2021).

\section{FUNDING}

This study was done through self-funding.

\section{DISCLOSURE}

The authors and declaration report no conflicts of interest for this work because they have no affiliation or involvement with any organization financially or association of any entity directly or indirectly with the subject matter or materials that this article presents. This includes expert testimony, honoraria, stocks or options ownership, employment, royalties, grants, or patents received or pending.

\section{CONFLICTS OF INTEREST}

The authors declare they have no relevant conflicts of interest.

\section{REFERENCES}

Ali A, Noman M, Guo Y, Liu X, Zhang R, Zhou J, Zheng Y, Zhang XE, Qi Y, Chen X, Men D. Myoglobin and C-reactive protein are efficient and reliable early predictors of COVID-19 associated mortality. Sci Rep. 2021;11(1):5975. https://doi.org/10.1038/s41598 021-85426-9

Costela-Ruiz VJ, Illescas-Montes R, Puerta-Puerta JM, Ruiz C, Melguizo-Rodríguez L. SARS-CoV-2 infection: The role of cytokines in COVID-19 disease. Cytokine Growth Factor Rev. 2020; 54:62-75. https://doi.org/10.1016/j.cytogfr.2020.06.001

Cui S, Chen S, Li X, Liu S, Wang F. Prevalence of venous thromboembolism in patients with severe novel coronavirus pneumonia. J Thromb Haemost. 2020;18(6):1421-1424. https://doi.org/10.1111/jth.14830

Favresse J, Lippi G, Roy PM, Chatelain B, Jacqmin H, Ten Cate H, Mullier F. D-dimer: Preanalytical, analytical, post-analytical variables, and clinical applications. Crit Rev Clin Lab Sci. 2018;55(8): 548-577. https://doi.org/10.1080/10408363.2018

Guan WJ, Ni ZY, Hu Y, Liang WH, Ou CQ, He JX, Liu L, Shan H, Lei CL, Hui DSC, Du B, Li LJ, Zeng G, Yuen KY, Chen RC, Tang CL, Wang T, Chen PY, Xiang J, Li SY, Wang JL, Liang ZJ, Peng YX, Wei L, Liu Y, Hu YH, Peng P, Wang JM, Liu JY, Chen Z, Li G, Zheng ZJ, Qiu SQ, Luo J, Ye CJ, Zhu SY, Zhong NS; China Medical Treatment Expert Group for Covid-19. Clinical Characteristics of Coronavirus Disease 2019 in China. N Engl J Med. 2020;382(18): 1708-1720. https://doi.org/10.1056/NEJMoa2002032.

Gupta M, Wahl B, Adhikari B, Bar-Zeev N, Bhandari S, Coria A, Erchick DJ, Gupta N, Hariyani S, Kagucia EW, Killewo J, Limaye RJ, McCollum ED, Pandey R, Pomat WS, Rao KD, Santosham M, Sauer M, Wanyenze RK, Peters DH. The need for COVID-19 research in low- and middle-income countries. Glob Health Res Policy. 2020; 5:33. https://doi.org/10.1186/s41256-02000159-y

Härter G, Spinner CD, Roider J, Bickel M, Krznaric I, Grunwald S, Schabaz F, Gillor D, Postel N, Mueller MC, Müller M, Römer K, Schewe K, Hoffmann C. COVID-19 in people living with human immunodeficiency virus: a case series of 33 patients. Infection. 2020;48(5):681-686. https://doi.org/10.1007/s15010-020$\underline{01438-\mathrm{z}}$

Jain S, Gautam V, Naseem S. Acute-phase proteins: As diagnostic tool. J Pharm Bioallied Sci. 2011;3(1):118-27. https://doi.org/10.4103/0975-7406.76489

Jeon J-S, Rheem I, Kim JK. C-Reactive Protein and Respiratory Viral Infection. Korean J Clin Lab Sci 2017; 49:15-21. https://doi.org/10.15324/kjcls.2017.49.1.15

Jiang SQ, Huang QF, Xie WM, Lv C, Quan XQ. The association between severe COVID-19 and low platelet count: evidence from 31 observational studies involving 7613 participants. Br J Haematol. 2020;190(1): e29-e33.

https://doi.org/10.1111/bjh.16817

Khalid A, Ali Jaffar M, Khan T, Abbas Lail R, Ali S, Aktas G, Waris A, Javaid A, Ijaz N, Muhammad N. Hematological and biochemical parameters as diagnostic and prognostic markers in 
SARS-COV-2 infected patients of Pakistan: a retrospective comparative analysis. Hematology. 2021;26(1):529-542. https://doi.org/10.1080/16078454.2021.1950898

Lala V, Goyal A, Bansal P, Minter DA. Liver Function Tests. [Updated 2021 Aug 20]. In: StatPearls [Internet]. Treasure Island (FL): StatPearls Publishing; 2021 Jan-. Available from: https://www.ncbi.nlm.nih.gov/books/NBK482489/ [Accessed November 14, 2021]

Letelier P, Encina N, Morales P, Riffo A, Silva H, Riquelme I, Guzmán N. Role of biochemical markers in the monitoring of COVID-19 patients. J Med Biochem. 2021;40(2):115-128. https://doi.org/10.5937/jomb0-29341

Li C, Li J, Ni H. Crosstalk Between Platelets and Microbial Pathogens. Front Immunol. 2020a; 11:1962.

https://doi.org/10.3389/fimmu.2020.01962

Li Q, Cao Y, Chen L, Wu D, Yu J, Wang H, He W, Chen L, Dong F, Chen W, Chen W, Li L, Ran Q, Liu Q, Ren W, Gao F, Chen $\mathrm{Z}$, Gale RP, Hu Y. Hematological features of persons with COVID19. Leukemia. 2020b;34(8):2163-2172. https://doi.org/10.1038/s41375-020-0910-1

Luan YY, Yin CH, Yao YM. Update Advances on C-Reactive Protein in COVID-19 and Other Viral Infections. Front Immunol. 2021 10; 12:720363. https://doi.org/10.3389/fimmu.2021.720363.

Maria pan V, Manohar an PS, R P, Shanmugam L, Rao SR, Pillai AB. Potential biomarkers for the early prediction of SARSCOV-2 disease outcome. Microb Pathog. 2021; 158:105057. https://doi.org/10.1016/j.micpath.2021.105057

Melo AKG, Milby KM, Caparroz ALMA, Pinto ACPN, Santos RRP, Rocha AP, Ferreira GA, Souza VA, Valadares LDA, Vieira RMRA, Pileggi GS, Trevisani VFM. Biomarkers of cytokine storm as red flags for severe and fatal COVID-19 cases: A living systematic review and meta-analysis. PLoS One. 2021;16(6): e0253894. https://doi.org/10.1371/journal.pone.0253894

Noris M, Benigni A, Remuzzi G. The case of complement activation in COVID-19 multiorgan impact. Kidney Int. 2020;98(2):314-322. https://doi.org/10.1016/j.kint.2020.05.013

Poudel A, Poudel Y, Adhikari A, Aryal BB, Dangol D, Bajracharya T, Maharjan A, Gautam R. D-dimer as a biomarker for assessment of COVID-19 prognosis: D-dimer levels on admission and its role in predicting disease outcome in hospitalized patients with COVID-19. PLoS One. 2021;16(8): e0256744.

https://doi.org/10.1371/journal.pone.0256744

Riley RS, Gilbert AR, Dalton JB, Pai S, McPherson RA. Widely Used Types and Clinical Applications of D-Dimer Assay. Lab Med. 2016;47(2):90-102. https://doi.org/10.1093/labmed/lmw001

Roberts J, Pritchard AL, Treweeke AT, Rossi AG, Brace N, Cahill P, MacRury SM, Wei J, Megson IL. Why Is COVID-19 More Severe in Patients with Diabetes? The Role of AngiotensinConverting Enzyme 2, Endothelial Dysfunction and the Immunoinflammatory System. Front Cardiovasc Med. 2021; 7:629933. https://doi.org/10.3389/fcvm.2020.629933

Samprathi M, Jayashree M. Biomarkers in COVID-19: An Up-To-Date Review. Front Pediatr. 2021; 8:607647. https://doi.org/10.3389/fped.2020.607647

Seyoum M, Enawgaw B, Melku M. Human blood platelets and viruses: defense mechanism and role in the removal of viral pathogens. Thromb J. 2018 17; 16:16. https://doi.org/10.1186/s12959018-0170-8

Shang Y, Pan C, Yang X, Zhong M, Shang X, Wu Z, Yu Z, Zhang W, Zhong Q, Zheng X, Sang L, Jiang L, Zhang J, Xiong W, Liu J, Chen D. Management of critically ill patients with COVID-19 in ICU: statement from front-line intensive care experts in Wuhan, China. Ann Intensive Care. 2020;10(1):73. https://doi.org/10.1186/s13613-020-00689-1

Sharma A, Jaiswal P, Kerakhan Y, Saravanan L, Murtaza Z, Zergham A, Honganur NS, Akbar A, Deol A, Francis B, Patel S, Mehta D, Jaiswal R, Singh J, Patel U, Malik P. Liver disease and outcomes among COVID-19 hospitalized patients - A systematic review and meta-analysis. Ann Hepatol. 2021;21:100273.

https://doi.org/10.1016/j.aohep.2020.10.001

Sharma A, Nagalli S. Chronic Liver Disease. [Updated 2021 Jul 5]. In: StatPearls [Internet]. Treasure Island (FL): StatPearls Publishing; 2021 Jan-. Available from: https://www.ncbi.nlm.nih.gov/books/NBK554597/ [Accessed November 14, 2021]

Singh J, Malik P, Patel N, Pothuru S, Israni A, Chakinala RC, Hussain MR, Chidharla A, Patel H, Patel SK, Rabbani R, Patel U, Chugh S, Kichloo A. Kidney disease and COVID-19 disease severitysystematic review and meta-analysis. Clin Exp Med. 2021:1-11. https://doi.org/10.1007/s10238-021-00715-x

Stringer D, Braude P, Myint PK, Evans L, Collins JT, Verduri A, Quinn TJ, Vilches-Moraga A, Stechman MJ, Pearce L, Moug S, McCarthy K, Hewitt J, Carter B; COPE Study Collaborators. The role of C-reactive protein as a prognostic marker in COVID-19. Int J Epidemiol. 2021;50(2):420-429. https://doi.org/10.1093/ije/dyab012

Tavakolpour S, Rakhshandehroo T, Wei EX, Rashidian M. Lymphopenia during the COVID-19 infection: What it shows and what can be learned. Immunol Lett. 2020; 225:31-32. https://doi.org/10.1016/j.imlet.2020.06.013

Terpos E, Ntanasis-Stathopoulos I, Elalamy I, Kastritis E, Sergentanis TN, Politou M, Psaltopoulou T, Gerotziafas G, Dimopoulos MA. Hematological findings and complications of COVID-19. Am J Hematol. 2020;95(7):834-847. https://doi.org/10.1002/ajh.25829

Thachil J, Cushman M, Srivastava A. A proposal for staging COVID-19 coagulopathy. Res Pract Thromb Haemost. 2020;4(5):731-736. https://doi.org/10.1002/rth2.12372

Udugama B, Kadhiresan P, Kozlowski HN, Malekjahani A, Osborne M, Li VYC, Chen H, Mubareka S, Gubbay JB, Chan WCW. Diagnosing COVID-19: The Disease and Tools for Detection. ACS Nano. 2020;14(4):3822-3835. https://doi.org/10.1021/acsnano.0c02624

Wang L. C-reactive protein levels in the early stage of COVID-19. Med Mal Infect. 2020;50(4):332-334. https://doi.org/10.1016/j.medmal.2020.03.007

Waris A, Din M, Khalid A, Abbas Lail R, Shaheen A, Khan N, Nawaz M, Baset A, Ahmad I, Ali M. Evaluation of hematological parameters as an indicator of disease severity in Covid-19 patients: Pakistan's experience. J Clin Lab Anal. 2021;35(6): e23809. https://doi.org/10.1002/jcla.23809

Wiersinga WJ, Rhodes A, Cheng AC, Peacock SJ, Prescott HC. Pathophysiology, Transmission, Diagnosis, and Treatment of 
Coronavirus Disease 2019 (COVID-19): A Review. JAMA. 2020;324(8):782-793. https://doi.org/10.1001/jama.2020.12839

Wool GD, Miller JL. The Impact of COVID-19 Disease on Platelets and Coagulation. Pathobiology. 2021;88(1):15-27. https://doi.org/10.1159/000512007

World Health Organization (WHO). WHO Coronavirus (COVID-19) Dashboard. 2021. Available https://covid19.who.int/ [Assessed January 2, 202].

World Health Organization. WHO Director-General's opening remarks at the media briefing on COVID-19 - 11 March 2020. 2000. Available at https://www.who.int/directorgeneral/speeches/detail/who-director-general-s-opening-remarks-atthe-media-briefing-on-covid-19---11-march-2020 [Accessed November 17, 2021]

Xie J, Covassin N, Fan Z, Singh P, Gao W, Li G, Kara T, Somers VK. Association Between Hypoxemia and Mortality in Patients with COVID-19. Mayo Clin Proc. 2020a;95(6):1138-1147. https://doi.org/10.1016/j.mayocp.2020.04.006

Xie Y, Wang Z, Liao H, Marley G, Wu D, Tang W.

Epidemiologic, clinical, and laboratory findings of the COVID-19 in the current pandemic: systematic review and meta-analysis. BMC Infect Dis. 2020b;20(1):640. https://doi.org/10.1186/s12879-020$\underline{05371-2}$

Xu P, Zhou Q, Xu J. Mechanism of thrombocytopenia in COVID-19 patients. Ann Hematol. 2020;99(6):1205-1208. https://doi.org/10.1007/s00277-020-04019-0

Yang M, Chen X, Xu Y. A Retrospective Study of the CReactive Protein to Lymphocyte Ratio and Disease Severity in 108 Patients with Early COVID-19 Pneumonia from January to March 2020 Wuhan, China. Med Sci Monit. 2020;26: e926393. https://doi.org/10.12659/MSM.926393
Yao Y, Cao J, Wang Q, Shi Q, Liu K, Luo Z, Chen X, Chen S, Yu K, Huang Z, Hu B. D-dimer as a biomarker for disease severity and mortality in COVID-19 patients: a case-control study. J Intensive Care. 2020; 8:49. https://doi.org/10.1186/s40560-020-00466-Z

Yu B, Li X, Chen J, Ouyang M, Zhang H, Zhao X, Tang L, Luo Q, Xu M, Yang L, Huang G, Liu X, Tang J. Evaluation of variation in D-dimer levels among COVID-19 and bacterial pneumonia: a retrospective analysis. J Thromb Thrombolysis. 2020;50(3):548-557. https://doi.org/10.1007/s11239-020-02171-y

Zhan H, Chen H, Liu C, Cheng L, Yan S, Li H, Li Y. Diagnostic Value of D-Dimer in COVID-19: A Meta-Analysis and Meta-Regression. Clin Appl Thromb Hemost. 2021; 27: 10760296211010976. https://doi.org/10.1177/10760296211010976

\section{How to cite this article}

Yusof YAM, Haque M. Biomarkers For The Detection of SARSCoV2-Virus and in the Prediction of COVID-19 Infection Severity. J App Pharm Sci, 2022; 12(02): i-v. 